\title{
QUEEN INFLUENCE ON WORKERS BEHAVIOR OF THE LEAF-CUTTING ANT Atta sexdens rubropilosa (FOREL, 1908)
}

\author{
SOUSA-SOUTO, L. and SOUZA, D. J. \\ Departamento de Biologia Animal, Universidade Federal de Viçosa, CEP 36570-000, Viçosa, MG, Brazil \\ Correspondence to: Leandro Sousa-Souto, Laboratório de Ecologia de Comunidades, \\ Departamento de Biologia Animal, Pós-graduação em Entomologia, Universidade Federal de Viçosa, \\ CEP 36570-000, Viçosa, MG, Brazil, e-mail: leandrosouto@insecta.ufv.br \\ Received May 7, 2004 - Accepted August 10, 2004 - Distributed May 31, 2006
}

(With 4 figures)

\begin{abstract}
In an ant colony, the queen is the single reproducer and can interact with her workers via pheromones and cuticular compounds. However, in most species queen importance is not restricted to reproduction: in the initial development of the colony, her presence might play a more important role. In this work, we studied the effects of queen absence on workers behavior displayed in the foraging arena. Ant's mortality and refuse accumulation was also measured daily. The results showed that queen absence did not alter either workers behavior or foraging efficiency. However, we observed increased ant mortality accompanied by a decrease in refuse dumping outside the nest. These results corroborate the hypothesis that environmental factors are more important than intrinsical factors in the allocation of external tasks. Probably, the queen could only influence internal activities of the colony.
\end{abstract}

Keywords: foraging, leaf-cutting ants, colony cohesion, ethogram.

\section{RESUMO}

\section{Influência da rainha no comportamento de operárias da formiga cortadeira Atta sexdens rubropilosa (Forel, 1908)}

Numa colônia de formiga, a rainha é a única que exerce a atividade de reprodução e sua interação com as operárias ocorre, principalmente, por meio de feromônios e compostos cuticulares. No entanto, em muitas espécies, a sua importância não está restrita à reprodução. Nos estágios iniciais do desenvolvimento da colônia, ela pode exercer um papel mais importante. Neste trabalho, foram estudados os efeitos da ausência da rainha no comportamento de operárias presentes na arena de forrageamento. A mortalidade de operárias e a acumulação de lixo também foi medida diariamente. Os resultados mostraram que a ausência da rainha não alterou o comportamento das operárias nem a eficiência de forrageamento. Entretanto, verificou-se o aumento da mortalidade diária acompanhado do decréscimo na deposição de lixo fora do ninho. Estes resultados corroboram a hipótese de que fatores ambientais são mais importantes do que fatores intrínsecos na alocação de tarefas externas. Provavelmente, a rainha atue apenas na influência de atividades internas da colônia.

Palavras-chave: forrageamento, formigas cortadeiras, coesão da colônia, etograma.

\section{INTRODUCTION}

In ant societies, the queen is the single colony member that reproduces and performs activities concerning reproduction. The queen is highly attractive to her own workers (Stumper, 1956; Glancey et al., 1982; Cammaerts, 1985; Vienne et al., 1998) and this attractiveness is mainly based on the emission of pheromones. These substances are, in general, different from the recognition signals of the colony members. The importance of the queen in the recognition process among nestmates may differ among different species with distinct 
social structures (Vienne et al., 1998). In some species, the queen is considered the main odor source of colony as in Camponotus spp. (Carlin \& Hölldobler, 1987), Leptothorax lichtensteini (Provost, 1987) and Linepithema humile (Keller \& Passera, 1989). On the other hand, in some species the queen does not seem to act in the recognition process, as shown in Cataglyphis niger (Lahav et al., 1998) and C. iberica (Dahbi et al., 1999).

In some cases, when the queen is removed, the colony continues to produce gynes from fertilized eggs previously laid by the queen, and males from eggs laid by workers (Heinze \& Oberstadt, 1999). It is known that in Atta and Acromyrmex, the colony dies after the queen's death, since she is the sole egg producer in the nest and the queen's replacement in the field has not been reported. In laboratory conditions, one A. sexdens rubropilosa colony lived up to three months after the death of the queen, which had lived 15 years (Autuori,1950). Recently, Della Lucia et al. (2003) described the colony behavior of A. sexdens rubropilosa after the queen's death. They found that foraging activities, fungal care and refuse manipulation were not directly affected by the queen's presence, but the efficiency of these activities was not measured.

Here, we tested if queen absence, in small colonies of $A$. sexdens rubropilosa alters the workers behavior in terms of external tasks, as well as refuse accumulation and the mortality rate of workers. The foraging efficiency - measured as time to find and transport resources - was evaluated. In addition, we also evaluated the possibility of alteration on interaction among workers at the foraging arena in response to queen's absence.

\section{MATERIAL AND METHODS}

\section{Colony maintenance}

Two colonies of A. sexdens rubroplilosa kept for over 4 years at the Unidade de Estudos de Ecologia de Comunidades - UEEC, at the Universidade Federal de Viçosa, Minas Gerais state - Brazil were used. The colony structures were: a ceramic pot connected to a rectangular foraging arena $(25 \times 15 \times 10 \mathrm{~cm})$ and to the other end a refuse box. The colony garden fungus' volume was about $1.5 \mathrm{~L}$. The colonies were kept at $26+2{ }^{\circ} \mathrm{C}$, relative humidity of $75+5 \%$, and LD 12:12 h cycle, and fed with Acalypha wilkesiana (Euphorbiaceae), Ligustrum japonicum (Oleaceae) leaves and Rosa sp. (Rosaceae) petals.

\section{Experimental design}

In order to establish the effects of the queen's absence on worker's behavior, the colonies were observed for 17 days. The queen's presence was observed in the first five days and then a period of ten days without the queen was monitored. There was an interval of two days between the first and second observational periods. The queens were kept in a $100 \mathrm{ml}$-plastic-pot with $50 \mathrm{ml}$ of fungus and 25 minimum and medium workers, fed with A. wilkesiana leaves in the period when they were absent.

During behavioral assays we observed: i) the behavioral repertory on the foraging arena; ii) the average time to find, cut and transport vegetal fragments to the colony; iii) the daily refuse production; and iv) the daily ant's mortality. If the queen has some influence on the internal colony activities, as expected, it would immediately be reflected on the refuse accumulation and on the ants' mortality. Likewise, if the queen influenced the external colony activities, its absence might has a negative effect on the foraging behavior and on the interaction among individuals in the foraging arena.

Workerbehavior was quantified in an ethogram (Wilson, 1980). A 30 min observation focused on workers present in the foraging arena. The main observed behavioral categories were autogrooming (AG), antennal touch (AT) and immobility (IM). Some other types of behavior, which were less frequent, such as refuse transporting, allogrooming, workers transporting and glossa to glossa contact were also computed when they were observed.

After observing the behavioral repertory, we left two A. wilkesiana leaves (of the same size) at the foraging arena. We registered the transport time of the first and $10^{\text {th }}$ fragment, in order to obtain an average measurement of foraging efficiency.

The refuse production was measured daily. In this way, we collected all refuse accumulated in the box. It was previously dried for $48 \mathrm{~h}$ in $60{ }^{\circ} \mathrm{C}$ and weighed on a pair of digital scales. Daily mortality was obtained by counting dead ants in the refuse pile. 


\section{Statistical analysis}

The behavior frequency (response variable) among the different categories (explanatory variable) was tested using ANOVA. The average weight of produced refuse between treatments (with and without the queen) was analyzed with the Wilcoxon rank test. The ants' mortality between treatments and during the observation period was tested using analyses of deviance, with generalized linear models (Crawley, 2002). The average time of collection of the first (T1) and the tenth fragment (T10) were analyzed using the Wilcoxon rank test. In the variance and deviance analyses, the observation period - days - was included in the statistical models as a temporal series variable and the unities of sampling -colonies - as nested variables into the treatment block (Crawley, 2002). In addition, the Wilcoxon rank test is more suitable to compare two sample means with non-normal errors (Crawley, 2002).

\section{RESULTS}

The frequency of behaviors among the different categories did not differ between treatments (nested ANOVA $\mathrm{F}_{3182}=0.9113$; $\mathrm{p}=0.436$ ) (Fig. 1), as well as the average time of cutting and transporting the first fragment to the nest ( $\mathrm{W}=135.5, \mathrm{p}=0.115)$. However, there was a decrease in the time of transporting the tenth fragment to the nest $(\mathrm{W}=168.5, \mathrm{p}=0.002$ ) (Fig. 2).

The average weight of the refuse accumulated was small in the period that the queen was absent in the colony ( $\mathrm{W}=151, \mathrm{p}=0.002$ ) (Fig. 3). On the other hand, despite the smaller weight of the refuse accumulated, ants' mortality increased in the same period (nested ANOVA $\mathrm{F}_{1.54}=5.7883$; $\mathrm{p}=0.023$ ) (Fig. 4). After the experiments, the queens were given back to their own colonies. At this moment, a certain agitation among the workers was observed, however the queen was promptly accepted and no aggressive behavior to the queen was noticed.

\section{DISCUSSION}

Our results suggest that $A$. sexdens rubropilosa queens do not play any important role on the behavior of workers engaged in external activities. A decrease in transporting time of the tenth fragment during the queen's absence does not indicate that the foraging activity has been affected. This decrease in time might be linked to the worker's conditioned behavior as the food was supplied at a same quantity and at the same time

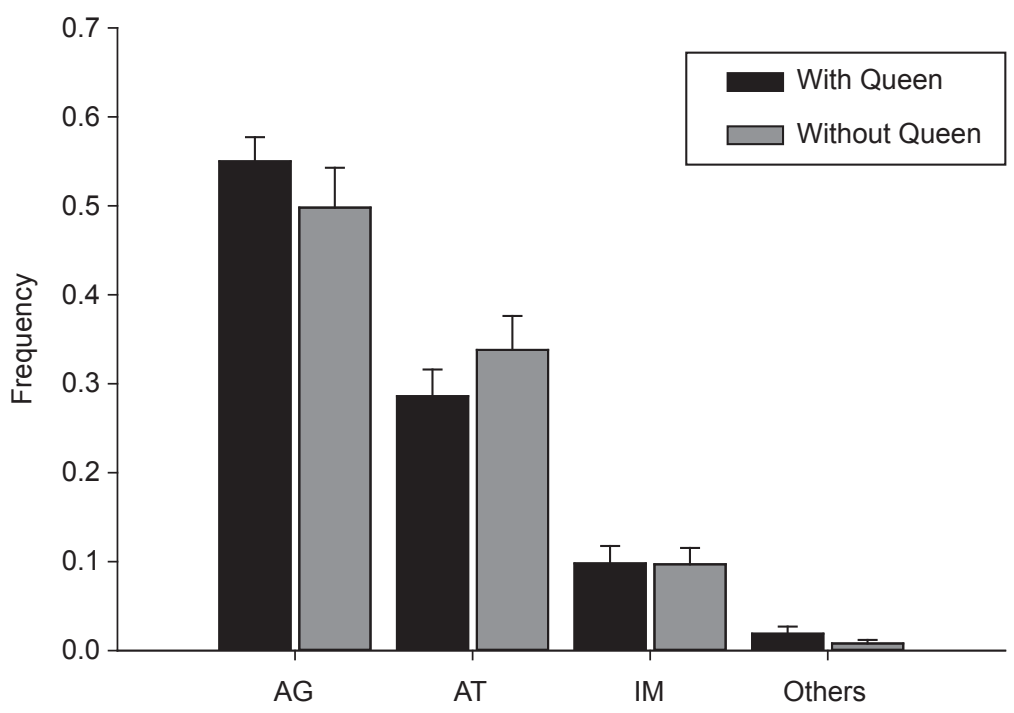

Fig. 1 - Frequency of main observed behaviors in response to the treatments (mean + SE). AG: Autogrooming; AT: Antenal touch, IM: Immobile. 


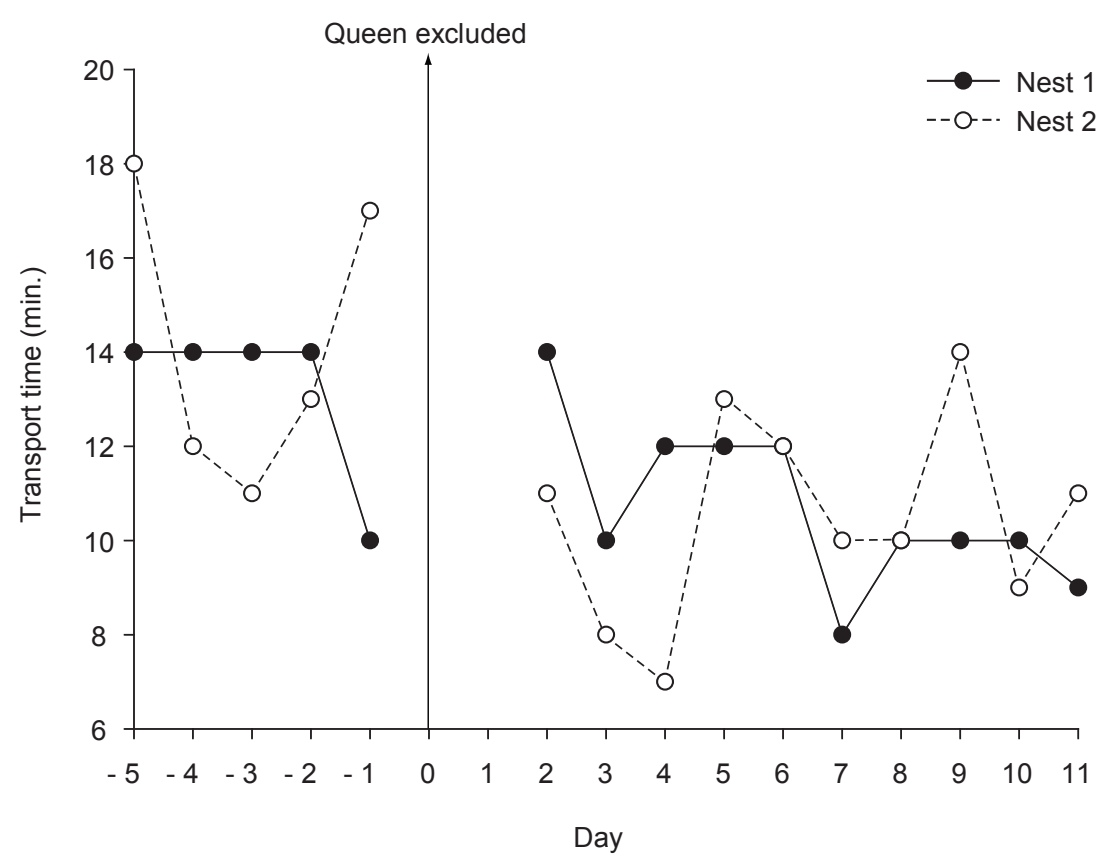

Fig. 2 - Time spent to transport the $10^{\text {th }}$ leaf-fragment during observation days. There was a decrease in transport time $(\mathrm{W}=168.5, \mathrm{p}<0.05)$. However, it may not be due to the queen's influence.

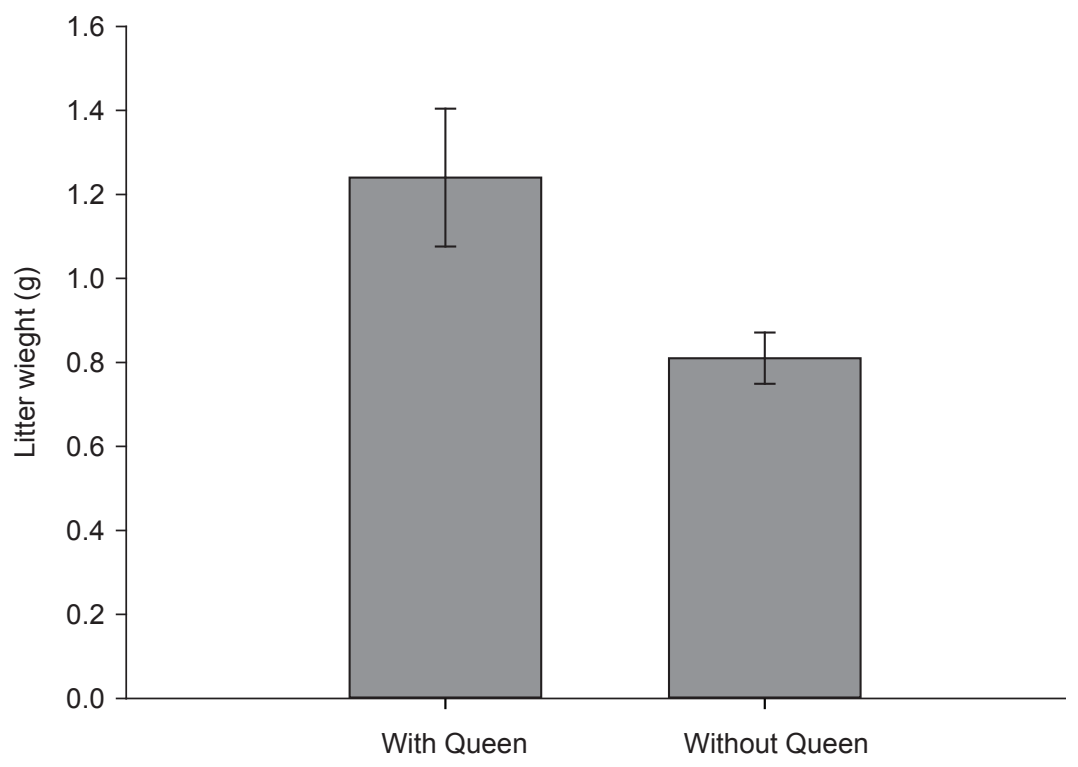

Fig. 3 - The daily weight of refuse accumulation between treatments (mean \pm SE). There was a weight decrease when the queen was excluded $(\mathrm{W}=151, \mathrm{p}=0.026)$.

throughout the experimental period. Conditioned behavior and learning in respect to distribution and quality of the resource have also been observed on the leaf-cutting ant Acromyrmex lundi (Roces, 1990; Roces, 1994).
Workers interact in different ways in the foraging arena, and the behavior shown is not only restricted to those concerning foraging activity. A high frequency of autogrooming independently of queen presence was also observed. It is recognized 


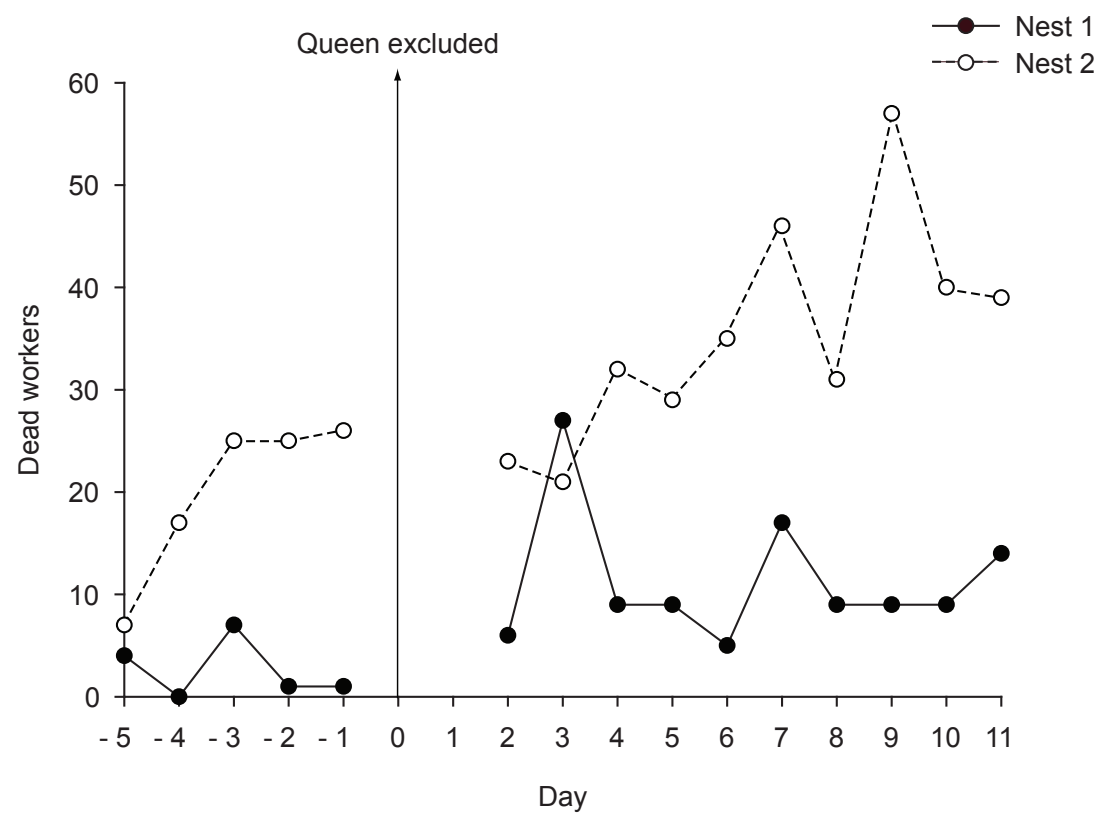

Fig. 4 - Number of dead ants throughout the observational period. There was increased ant mortality when the queen was excluded (nested ANOVA $\mathrm{F}_{1.54}=5.8 ; \mathrm{p}=0.023$ ). Days 0 and 1 include the interval period between treatments.

that the main function of this behavior would be a worker aseptic (Hölldober \& Wilson, 1990), but it might also be associated to the reinforcement of recognition signals among nestmates. The most frequent second behavior was antennal touch. Taking this into account, cephalic recognition signals might be transferred to legs and antennae. The recognition occurs when two nestmate workers touch their appendices. Thus, it explains the constant need of reinforcement in signals of recognition. In the queen's absence, there was a decrease in refuse accumulation, allied to the increase in the daily ant's mortality. This fact may be related to a tendency of disruption of colony internal tasks, such as fungus garden maintenance and brood care.

Abandoning the cleaning activity in the colony should lead to an increase in the ant's mortality. The accumulation of refuse inside and outside the colony could increase the worker's mortality owing to an increase of parasites (Bot et al., 2001). In addition, Della Lucia et al. (2003) found a trend of rupture in the colony cohesion in the queen's absence of A. sexdens rubropilosa.

Since the queen's absence did not alter the foraging behavior or foraging efficiency of workers in small A. sexdens rubropilosa colonies, it reinforces the assumption that task allocation is not due to hierarchical control, but to continuous adjustment processes in the colony due to environmental factors (Gordon, 1996). However, the study of the queen's influence on the internal activities that are related to a greater interaction among workers (such as fungus garden maintenance and brood care) needs a more complex investigation.

In this paper, regardless of an increase in workers mortality, it was found that the queen's absence of A. sexdens rubropilosa did not affect workers foraging behavior, neither the interactions among them in the foraging arena.

Acknowledgments - We are very grateful to K. Kitayama, C. Lopes, C. Ribas and M. Teixeira for their suggestions, J. Schoereder for providing laboratory space and the ant nests and C. Miller for the English review. The authors were supported by CAPES and FAPEMIG.

\section{REFERENCES}

AUTUORI, M., 1950, Longevidade de uma colônia de saúva (Atta sexdens rubropilosa Forel, 1908) em condições de laboratório. Arq. Inst. Biol., 18: 40-70. 
BOT, A. N. M., CURRIE, C. R., HART, A. G. \& BOOMSMA J. J., 2001, Waste management in leaf-cutting ants. Eth. Ecol. Evol., 13: 225-237.

CAMMAERTS, M. C., 1985, Etude de facteurs expliquant la variabilité des groupements d'ouvrières de Myrmica rubra L. autour de leurs reines. Ann. Soc. R. Zool. Belg., 115: 13-28.

CARLIN, N. F. \& HÖLLDOBLER, B., 1987, The kin recognition system of carpenter ants (Camponotus spp.) II. Larger colonies. Behav. Ecol. Sociobiol., 20: 209-217.

CRAWLEY, M. J., 2002, Statistical computing: an introduction to data analysis using S-Plus, 761p. John Wiley and Sons, LTD.

DAHBI, A., HEFETZ, A., CERDÁ, X. \& LENOIR, A., 1999, Trophallaxis mediates uniformity of colonial odor in Cataglyphis iberica ants (Hymenoptera, Formicidae). J. Ins. Behav., 12: 559-567.

DELLA LUCIA T. M. C., PETERNELLI E. F. O., LACERDA F. G., PETERNELli L. A. \& MOREIRA, D. D. O., 2003, Colony behavior of Atta sexdens rubropilosa (Hymenoptera: Formicidae) in the absence of the queen under laboratory conditions. Behav. Proc., 64: 49-55.

GLANCEY B. M., LOFGREN C. S., ROCCA J. R. \& TUMLISON, J. H., 1982, Behaviour of disrupted of Solenopsis invicta toward queens and pheromone-treated surrogate queens placed outside the nests. Sociobiology, 7: $283-288$.

GORDON, D. M., 1996, The organization of work in social insect colonies. Nature, 380: 121-124.

HEINZE, J. \& OBERSTADT, B., 1999, Worker age, size and social status in queenless colonies of the ant Leptothorax gredleri. Anim. Behav., 58: 751-759.
HÖLLDOBLER, B. \& WILSON, E. O., 1990, The ants, 732p., Harvard University, Cambridge.

KELLER, L., PASSERA, L., 1989, Influence of the number of the queens on nestmate recognition and attractiveness of queens to workers in the Argentine ant Iridomyrmex humilis (Mayr). Anim. Behav., 37: 733-740.

LAHAV, S., SOROKER, V., VANDER MEER, R. K. \& HEFETZ, A., 1998, Nestmate recognition in the an Cataglyphis niger: do queens matter? Behav. Ecol. Sociobiol., 43: 203-212.

PROVOST, E.,1987, Role of queen in intra colonial aggressivity and nestmate recognition in Leptothorax lichtensteini ants. In: J. Eder \& H. Rembold (eds.), Chemistry and Biology of Social Insects. Verlag J. Peperny, Munich.

ROCES, F., 1994, Odour learning and decision-making during food collection in the leaf-cutting ant Acromyrmex lundi. Insect. Soc., 41: 235-239.

ROCES, F., 1990, Olfactory conditioning during the recruitment process in a leaf-cutting ant. Oecologia, 83: 261-262.

STUMPER, R., 1956, Les secretions attractives des reines de fourmis. Mitt. Schweiz. Ent. Ges., 29: 373-380.

VIENNE C., ERRARD C. \& LENOIR A., 1998, Influence of the queen on worker behaviour and queen recognition behaviour in ants. Ethology, 104: 431-446

WILSON, E. O., 1980, Caste and division of labor in leaf-cutter ants (Hymenoptera: Formicidae: Atta). Behav. Ecol. Sociobiol., 7: 157-165. 